\title{
Model of Social Entrepreneurship Career Readiness among Malaysian Public University Students
}

\section{Anis Adibah Zamry \& Sheerad Sahid}

To Link this Article: http://dx.doi.org/10.6007/IJARBSS/v11-i12/11698

DOI:10.6007/IJARBSS/v11-i12/11698

Received: 12 October 2021, Revised: 16 November 2021, Accepted: 27 November 2021

Published Online: 24 December 2021

In-Text Citation: (Zamry \& Sahid, 2021)

To Cite this Article: Zamry, A. A., \& Sahid, S. (2021). Model of Social Entrepreneurship Career Readiness among Malaysian Public University Students. International Journal of Academic Research in Business and Social Sciences, 11(12), 1841-1858.

\section{Copyright: @ 2021 The Author(s)}

Published by Human Resource Management Academic Research Society (www.hrmars.com)

This article is published under the Creative Commons Attribution (CC BY 4.0) license. Anyone may reproduce, distribute, translate and create derivative works of this article (for both commercial and non0-commercial purposes), subject to full attribution to the original publication and authors. The full terms of this license may be seen at: http://creativecommons.org/licences/by/4.0/legalcode

Vol. 11, No. 12, 2021, Pg. 1841 - 1858

Full Terms \& Conditions of access and use can be found at http://hrmars.com/index.php/pages/detail/publication-ethics 


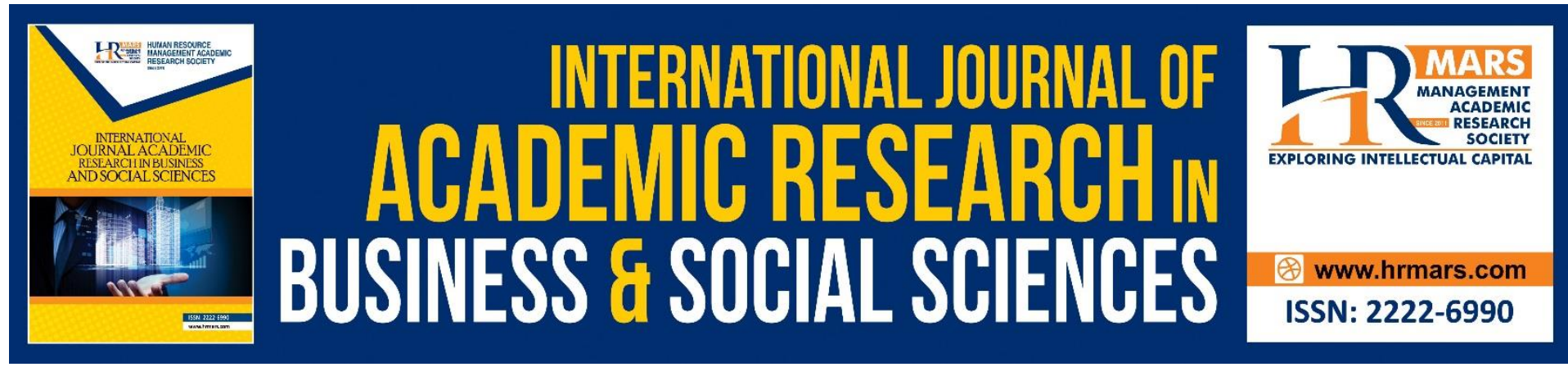

\title{
Model of Social Entrepreneurship Career Readiness among Malaysian Public University Students
}

\author{
Anis Adibah Zamry \& Sheerad Sahid \\ Faculty of Education, Universiti Kebangsaan Malaysia, UKM
}

\begin{abstract}
Social Entrepreneurship offers a unique opportunity to challenge, question and conceive concepts and assumptions in business management and research topics, as well as research methods and disciplines. The social entrepreneurship debate is a process of social change and/or addressing important social needs in a way that does not jeopardize the overall economic interests of the company. Social entrepreneurship differs from other forms of entrepreneurship in that it relatively prioritizes the promotion and development of social values over the acquisition of economic value. However, there is currently limited information on the level of international and social tuition fees for students in Malaysia. Nowadays, entrepreneurship and social entrepreneurship are considered viable work options and the career readiness elements do not only help improve the abilities and skills of prospective graduates but also increase the confidence of these graduates when entering the working world. The development of social cognition at the highest levels will have a profound impact on society and the combination of students or academics with university and society makes social entrepreneurship an important university curriculum, which is in the real life of learning and practice. Therefore, this concept paper aims to discuss and propose a conceptual framework of social entrepreneurship career readiness among public university students. Finally, social entrepreneurship is hoped to contribute to the ideas of prospective graduates as future careers can also contribute to positive and effective job creation with the ability to change perspectives and focus on social business to motivate them.
\end{abstract}

Keywords: Career Readiness, Social Entrepreneurship Career, Social Entrepreneurship, Social Entrepreneurship in Entrepreneurship Education, Career Readiness in Social Entrepreneurship.

\section{Introduction}

As reported by the International Labour Organization, the global unemployment rate fell from $1 \%$ to a stable $5 \%$ in 2018 , which is the lowest since the economic crisis hit the labour market. The 2021 World Employment and Social Outlook Trends report written by (Gomis et al., 2020) further emphasizes that the unemployment rate is expected to fall to $5.7 \%$ this year. The Covid-19 pandemic is estimated to increase the total unemployment from 187 million in 2019 to 220 million in 2020. On the one hand, job creation and the increase in skills and economic capabilities need to be prepared for more skilled jobs, whereas on the other hand, 
it is necessary to create jobs that are relevant to the usable workforce population. However, there are several ways to end the unemployment crisis, these are among the effective ways to bring relevant skill development policies to promote various sectors with financing, develop the social enterprise sector, or build the socio-economy. In this regard, social entrepreneurship does not only help overcome poverty and create social integration, but it also helps create productive jobs.

According to an intergovernmental organization (Brock \& Steiner, 2009), the UN mention the role of social entrepreneurs in the fight against unemployment by launching the UPSHIFT program, UNICEF (Kannampuzha \& Hockerts, 2019), along with discussions by Klaus Schwab, founder, and CEO of the Forum the World Economy stating that "suppliers, communities, and the environment can all benefit.". Nobel Peace Prize laureate Mohammad Yunus also believes that social institutions arise from the need to test each other's abilities and believes that joint efforts should be made to protect the environment. According to the parable of the social entrepreneur, "many birds are shot with one stone." This allows people to harness their potential, earn a better life, and work to Improving the lives of consumers, regardless of socioeconomic status, which all encompasses the general well-being of the environment. It is done with this in mind; thus, social entrepreneurship provides many benefits to ecosystem stakeholders and ultimately the entire ecosystem. As noted above (Guritno et al., 2019), Social Entrepreneurship as an expression of organizational "Social Innovation" is a demonstration of alternative work models based on the current challenges of a new world, a new society, and a new economy. As the role of human resources evolves and its function extends beyond the role of the organization to society, it is important that human resource managers understand the opportunities in this new field and what it means to them. "Lack of access to support and counselling services, lack of funds, lack of technical competence and lack of understanding of social enterprises are obstacles to development." he added.

This concept paper helps develop the field of social entrepreneurship in students' careers, which is important because it provides a framework for companies to successfully help others. This has always been a source of encouragement for employees, especially for the $Y$ generation, who are increasingly sceptical of the company's work environment. In addition, this can provide exposure to stakeholders such as universities, organizations, and businesses because the importance of increased support in the sector, combined with the growing frustration with social problems, creates a social enterprise where students can focus on regional, national, and international issues. They use academic and cultural backgrounds to communicate their businesses with people from all fields including science, engineering, business, and humanities.

\section{Social Entrepreneurship}

Social entrepreneurship is an idea, practice, or business term that attracts the attention of organizations that do not rely solely on profit. Social entrepreneurs set up and operate social enterprises and do not benefit directly from the profits of companies run by entrepreneurs or the distribution of wealth. According to previous studies, all social enterprises are assets and accumulated wealth not owned by individuals such as independent social enterprises, services for social purposes, goods, trade offerings, and distribution of nonprofit organizations. In social enterprise, profits are used to create more jobs and businesses and to generate wealth for society. Social entrepreneurs are agents of change in the vision of social enterprises committed to corporate behaviour for social purposes that promote the commercial activities of non-profit or social enterprises that support their mission (Tishler, 
2018). Social entrepreneurship consists of various perspectives in past research. In this context, social entrepreneurship refers to innovative activities with a social purpose, either in the profit sector such as point-based business social purpose business (Abdul Kadir \& Mhd Sarif, 2016) or research-basedcorporate social entrepreneurship (Vallejo-Fiallos, 2019), or in non-profit sectors or across sectors such as the mixed-method structure of profit and nonprofit methods (Roper \& Cheney, 2005).

Another definition from a past research (Thompson, 2002) said perspective is that social entrepreneurship identity generally refers to the application of business and marketing skills in the non-profit sector, where non-profit organizations create new ways to generate revenue. A large proportion of social entrepreneurship is defined by the driving force of social entrepreneurship is the creation of social values, not personal property or ownership of shareholders (Noruzi et al, 2010) and this activity is a function of innovation or innovation, not a copy of an existing business or process and not a mere business copy or existing practices. The main driver of social entrepreneurship constitutes the social problems it solves, and the specialized form of organization adapted by the social enterprise must entail the appropriate form of organization based on the most effective mobilization of resources necessary to solve this problem. Thus, social institutions are not limited to organizational and legal forms, as they can be implemented in different ways. Among other things, there are examples of social entrepreneurship in various fields. Similarly, social entrepreneurship is defined as the response to market failures due to continuous innovation. The purpose of solving social problems with change and financial resources (Ab Wahid et al., 2016), the three important things are as follows:

1. Respond to market failure

2. Recent changes

3. Financial stability

There are some theoretical and practical debates about social entrepreneurship that can be discussed in this concept, namely the theory and practice of social entrepreneurship, the definition of social entrepreneurship and the field of social entrepreneurship.

\section{a. Theory and Practice in Social Entrepreneurship}

Theories that can be discussed in social entrepreneurship are taken from a previous study by (Bacq \& Janssen, 2011), which refers to the study by (Dees \& Anderson, 2006) as shown in Table 1, namely the Spectrum of Social Enterprise. The study explains that social entrepreneurship is described as an activity between pure philanthropy and pure trade with a mixture of motivations, methods, goals, and the nature of key stakeholders. In general, social entrepreneurship has always been associated with the use of entrepreneurial and innovative approaches to address social problems. However, in a strict sense, social entrepreneurship is aimed at creating innovative social enterprises with financial sustainability and distribution constraints. The circle of social entrepreneurship has grown rapidly in recent years and has become a social, economic, and cultural phenomenon. According to (Mair \& Marti, 2004), Some governments are unable to meet the social needs of their constituents as the gap between rich and poor is widening in many developing countries with many business circles, problems, personal stories, and unattractive hopes to "change the world during an economic crisis." Individuals can inspire from the case of caring and visionary entrepreneurs who create solutions to unmet social needs and the main goal is to help others, where traditional forms of capitalism are a source of hope in a market where they struggle to 
rebuild reputation and legitimacy. Besides, other research perspectives such as from (Dacin et al., 2011) mentioned a quieter acceptance of social entrepreneurship. More and more researchers are venturing into the context of exciting social entrepreneurship and interdisciplinary, while researchers continue to struggle to define the boundaries of the field and come up with relevant and meaningful research questions. As a result, cognitive social studies remain in the fatal state and receive little attention (Short et al, 2019). However, most scholars agree that, due to the nature and knowledge of different fields in the field of social entrepreneurship, broader disciplines should be adopted, first, to introduce this structure into a new field.

Table 1: Spectrum of Social Enterprise

Purely Philanthropic

Punely Commercial

\begin{tabular}{|c|l|l|c|c|}
\hline \multicolumn{2}{|c|}{$\begin{array}{c}\text { Motives, Methods, and } \\
\text { Goals }\end{array}$} & $\begin{array}{c}\text { Appeal to goodwill } \\
\text { Mission driven } \\
\text { Social Value }\end{array}$ & $\begin{array}{c}\text { Mixed motives } \\
\text { Mission and market } \\
\text { driven } \\
\text { Social and economic } \\
\text { value }\end{array}$ & $\begin{array}{c}\text { Appeal to self- } \\
\text { interest } \\
\text { Market driven } \\
\text { Economic value }\end{array}$ \\
\hline $\begin{array}{c}\text { Key } \\
\text { Stakeh } \\
\text { olders }\end{array}$ & Beneficiaries & Pay nothing & $\begin{array}{c}\text { Subsidized rates, or } \\
\text { mix of full payers } \\
\text { and those who pay } \\
\text { nothing }\end{array}$ & Market-rate prices \\
\cline { 2 - 6 } & Capital & $\begin{array}{l}\text { Donation and } \\
\text { grants }\end{array}$ & $\begin{array}{c}\text { Below-market } \\
\text { capital, or mix of } \\
\text { donations and } \\
\text { market-rate capital }\end{array}$ & Market-rate \\
capital \\
\cline { 2 - 6 }
\end{tabular}

Source: (Dees \& Anderson, 2006)

\section{b. Social Entrepreneurs}

Social entrepreneurs are individuals and groups that seek large-scale sustainable change through ideas that break the patterns of what the governments, non-profits, and businesses do to address important social problems that involve networks, organizations, or affiliates of organizations (Hwee Nga \& Shamuganathan, 2010). This definition encompasses the eight fundamentals of transforming a social entrepreneur, his or her social enterprise organization, and an organization with a few entrepreneurs to achieve the goals of a social entrepreneur under construction, existing, or fully developed. The assumption for social entrepreneurs is that they should not only involve individuals, but also that they can create small groups or groups of individuals, organizations, networks, or communities to modify the model. This assumption distracts individual research, while increasing the social number of potential entrepreneurs (Short et al, 2019). Moreover, this refers to social entrepreneurs who are looking for a big and sustainable change. Given the deliberate nature of the modern debate, this assumption shifts the field from the question of who an entrepreneur is to what the 
entrepreneur wants, including the amount of potential social entrepreneurship that may exist at the same time (Noruzi et al., 2010). Social entrepreneurship can contain breakthrough ideas about how or what you can do to address important social problems. This concept shifts the purpose to a broader definition of social enterprise, which includes organizational and administrative reforms "using the old to the new". He also cites a study (Augier et al, 2016) that describes social business thinking (or the school of marketing) as a combination of the "social entrepreneurial innovation" and the "school of social innovation" found in this study. According to (Noruzi et al., 2010), this assumption opens discussions outside of non-profit organizations, including various industries and multidisciplinary organizations. In this sense, it is more difficult to start and maintain social institutions, for example if something involves a risk to social entrepreneurship.

\section{c. Scope of Social Entrepreneurship}

Many terms and definitions accepted by researchers and policymakers have rejected social entrepreneurship research. Social enterprise is described in various ways as "private enterprise for public interest" (Schleicher, 2020) in OECD 1999 profitable social enterprise (Dees \& Anderson, 2006) and corporate social objective (Abdul Kadir \& Sarif, 2016). In addition, social enterprises apply various forms of law and comply with different legal frameworks and tax responsibilities in different countries. These factors now make the comparisons of domestic and international social enterprises unreliable. Although it is universally accepted, there is no definition of social entrepreneur, social enterprise, or social entrepreneur (Oliveri et al., 2017) and there seems to be a contagious consensus on the meaning of social enterprise, while social entrepreneurs and social withdrawal are possible for defining companies (Haugh, 2005). In addition, (Chauhan, 2020) states that, for each topic, they propose the scope of future social entrepreneurship research of among the most significant challenges faced by social entrepreneurs that include recruitment, motivation, retention and training of trustees, employees, and volunteers' skill-based abilities. The reason is that it is not surprising to know that social entrepreneurial talent has emerged as the most explored topic. Furthermore, he added that researchers can also study issues related to the social personality traits of entrepreneurs, social entrepreneurial identity, women social entrepreneurs, and human capital.

Another small research group has focused on education and training for social entrepreneurs. The characteristic or scope of social entrepreneurship aims to create a social enterprise that implements a business model. To address social problems and create social impacts (Ashour, 2016) through the "social element" of social entrepreneurship, many studies have focused on the social impact, social change led by social entrepreneurship, social mission, and the social capital generated by social entrepreneurs. This past study has also focused on the efforts of social entrepreneurs, while social problems collected by past researchers include poverty, health, education, and unemployment. However, according to (Mair \& Marti, 2004), some areas under this theme are not well explored, for example, the involvement of social entrepreneurship in prominent social problems related to gender inequality, gender discrimination, the rights and safety of women and children, and women's empowerment. Business strategy and value creation by social enterprises are guided by social mission; therefore, the success of a business strategy depends on the factors that are completely different from the enterprise. Past researchers have also been particularly interested in examining social entrepreneurship business models, social entrepreneurship business performance, social entrepreneurship marketing strategies, value creation and distribution, 
and the internationalization of social entrepreneurship. Therefore, research in the field or scope of social entrepreneurship is still many and needs to be studied by future researchers in more depth and more widely.

\section{Elements of Career Readiness}

Yashveer Singh, the co-founder, and global director of Ashoka Young Changemakers, believes that every organization in the world is undergoing a major change and it is no longer enough for them to hire someone with a particular skill and expect that skill to be relevant to their age. "For an organization or company to grow, it needs people who can continuously and effectively adapt and experience these changes, as well as help others grow as drivers of change, " he said. (Raftopoulos et al., 2009) argued that many social entrepreneurs around the world are currently learning new skills to create opportunities for underprivileged people and are trying to create jobs, either directly or indirectly. Some are also working systematically to bring about policy changes in the world for jobs and livelihoods for everyone. Another social entrepreneur who won the UN Environmental Leadership Award, Vaibhav Tidke, CEO of S4S Technologies, highlighted how social entrepreneurs are challenging the traditional employment models. (Prikshat et al., 2018) stated that many social entrepreneurs have similar problems. While the future of social entrepreneurship looks promising, there are many obstacles to their growth. As a sector, social entrepreneurs have contributed to job creation and job skills development, and they have long been an important impetus for improving employment conditions across the country. Therefore, the growth of social entrepreneurship in higher education will have a greater impact on society. The combination of students or graduates with college and community authorities makes classroom or college social entrepreneurship an important course to learn and apply in real life. According to (Makki et al., 2015), the learning model facilitates the teaching and learning process of educators and students through a standard learning process. We can change our perspectives and encourage them to start focusing on social entrepreneurship to provide more ideas in supporting the evolution of entrepreneurship. Therefore, the elements of career readiness discussed in this concept paper are as follows:

\section{a. Knowledge Skills and Student Quality Skills}

Employers place a great value on job preparation (Warnick et al., 2018), which means having the skills, knowledge, attitude, and understanding of business that allows new graduates to make productive contributions to the achievement of organizational goals, grades, skills, and knowledge of students as important preparation to the working world (Oliveri et al., 2017). (de Villiers, 2010) emphasized that employers and graduates need to have a consensus on job preparation skills in terms of self-discipline, self-confidence, leadership, number skills, and problem-solving skills. Workplace self-preparation is explained through the characteristics of workplace preparation, such as the application of a new culture, awareness of skills, and group work. For instance, Kanungo \& Company Benchmarking and Job Readiness Review provides a framework to improve education and training to meet the needs of existing jobs in India. Within the framework, they stated that those willing to work have initial skills and minimum job qualifications to apply new skills and changes, learn good work ethics, and take care of their health and work. European business institutions also encourage students to increase graduate mobility and create flexible, skilled, and hard-working people who meet the needs of modern European enterprises (de Villiers, 2010). Besides, the capacity of social entrepreneurs is needed to grow effectively through integrated knowledge development 
programs. On the other hand, the effectiveness of social enterprise development programs for building successful social enterprises has not been fully studied. (Guritno et al., 2019) explained that the American University Faculty of International Services program for social entrepreneurship can prepare students for knowledge and skills in the field of social entrepreneurship. Dees, the father of social enterprise education, believes that it is not educational programs that encourage students to begin social activities as soon as they graduate; they may not have the experience and skills to lead the effort, or it may be difficult to attract the necessary resources (Worsham et al., 2012).

\section{b. Motivation}

Previous studies (Ghalwash et al., 2017) have argued that the existing studies have paid little attention to social problems regarding business identity and motivation, especially in developing countries (Germak \& Robinson, 2013). Although empirical research on social entrepreneurs is generally increasing, little attention has been paid to how social entrepreneurs are motivated even though there are important theoretical and empirical studies on the motives of commercial entrepreneurs. To fill the literature gaps, (Ghalwash et al., 2017) examines the characteristics and motivations of Egyptian social entrepreneurs. (Doherty, 2015) and (Seelos \& Mair, 2005) characterized social entrepreneurs as social heroes who benefit from their talents and skills. Similarly, (Doherty, 2015) described social entrepreneurs as creative individuals.

\section{c. Entrepreneurial Ability}

While empirical studies on the effectiveness of social enterprise (Wronka-Pośpiech, 2016) are still somewhat vague, the studies still offer interesting steps towards competencies related to social entrepreneurship. According to one of the experiments conducted by (Gasparin et al., 2021) and (Karlesky, 2015) on the extent to which the respondents believe that certain skills are important for the education of social entrepreneurs, the results of the online survey involving 150 respondents comprising senior executives, social entrepreneurs, founders, and social venture capitalists found that the key skills assessed in the United States are as follows:

1. Problem-solving ability.

2. Ability to form effective teams.

3. Treasury and capital management functions.

4. Ability to lead and manage the organization.

5. Ability to communicate with customers, suppliers, and other parties.

Similarly, based on previous research by (Saebi et al., 2018), the seriousness of research teams related to entrepreneurship for social purposes constitutes the ability to raise funds such as books on the roles of businesses and those that can influence the ability to shape entrepreneurial ventures (Warnick et al., 2018). Both studies have demonstrated the importance of a better understanding of the behavioural formation mechanisms at the molar level, suggesting that more studies could significantly improve the understanding of social entrepreneurs. Since there is still little research on the capabilities of social entrepreneurs, this study, therefore, aims to further examine whether entrepreneurship is related to professional preparation as a social entrepreneur. 


\section{d. Opportunity Recognition}

According to (Monllor \& Attaran, 2008), researchers in social enterprises have consistently acknowledged in their writing that social cognition is an important characteristic of social entrepreneurs. (Thompson, 2002) defines a social entrepreneur as someone who "knows where the national welfare system cannot meet or has the opportunity to meet unexpected needs that cannot be met." Past researchers then developed the four steps involved in the social entrepreneurship process (Thompson, 2002):

1. Imagine: See opportunities

2. Get involved: Take a chance with your heart and do something about it.

3. Activation: Get the resources you need and see what happens.

4. Essay: Promotion and project leadership.

Based on a study that proposed a creativity model of implicit opportunity recognition (Monllor \& Attaran, 2008), opportunity recognition is the first step in this process. Thompson conducted a case study to clarify the four key themes of his framework and found that opportunities are the core of efforts, and they are creative. Meanwhile, (Seelos \& Mair, 2005) stated that social entrepreneurs recognize opportunities, improve systems, find solutions, and take actions to create new approaches to social problems. According to (Hwee Nga \& Shamuganathan, 2010) based on (Dees, 1998), social entrepreneurship is defined by stating the role of change through:

1. Following a mission to create and maintain social values.

2. Recognizing and exploring new opportunities to fulfill missions.

3. Participating in the process of innovation, adaptation, and continuous learning.

4. Acting boldly without being limited by available resources.

5. Demonstrating high responsibility to the voters and results achieved.

\section{Social Entrepreneurship in Entrepreneurship Education}

According to (Indrasari et al., 2018), to foster professional social entrepreneurship in a country, some governments and public policymakers use the elements of an effective business education system to develop quality social entrepreneurship nature and we need to educate our citizens on its benefits. This is based on a survey by the American Business Education Consortium, which shows five levels of entrepreneurship. Social entrepreneurship is a socio-economic talent for the public interest and a kind of good education that combines self-interest and altruism. According to (Sánchez, 2013), promoting social entrepreneurship of college students at a higher level may not only develop important skills for the students but also lead to the formation of leadership skills. As such, today's ideas enhance the entrepreneurial character and morale of students, rebuild social fashion for future social and economic development, and give students a sense of social responsibility, social values, and social responsibility. Everyone agrees that social entrepreneurship has been existing for a long time and the formation of this practice for social entrepreneurs entails the formation of professionals and scholars, with more and more interest among them. Non-profit organizations seek alternative funding to maintain their operations and independence. One option is to generate profit by offering a product or service; therefore, the idea of social enterprise is based on revenue-generating strategies. Additionally, institutional-related research publications will also benefit from non-profit interests and become more commercial (Teng et al., 2018). As a result, it can be discussed in extra-curricular activities and social entrepreneurship. 


\section{a. Additional-Curricular Activities}

Extracurricular or off-campus entrepreneurship activities are important in entrepreneurship education to enhance formal entrepreneurship education by letting students lead in their activities, thereby giving the students additional space to lead outside the curriculum (Bagheri and Pihie, 2010). (Claudia, 2014) defined entrepreneurship as a non-traditional activity that is innovative, contains risk factors, and leads to financial reassessment. Additional activities in the entrepreneurship curriculum include behaviours, experiences, novelties, and, of course, learning processes related to the creation of new businesses. Meanwhile, business education is a non-traditional business discipline and there is no dominant educational model; hence, additional-curricular activities should be used (Bagheri and Pihie, 2010). In addition, additional-curricular activities are behavioural and empirical. Actions can be represented by three parts: action, experience gained in the process of interpretation, and learning gained from experience (Pittaway et al., 2011). Besides, curriculum supplemental activities include active students and whether these actions motivate students to acquire tacit knowledge about active behaviour. Additional activities are also intended to educate, inspire, and promote business interests as well as reinforcing learning and improving job performance or acquiring business skills for the purpose of developing a student's talents. Thus, it is important to learn what is relevant to the future of business (Edwards, 2001) and help students manage their time better.

\section{b. Additional-Curricular Activities and Social Entrepreneurship}

The most common form entails entrepreneurs who want to educate, inspire, and promote their interest in business while enhancing their work capabilities or acquiring skills related to future business creation as well as industry groups aimed at developing skills (Edwards, 2001). Entrepreneurial clubs and associations tend to participate in many activities, including various combinations: entrepreneurial speeches; networking opportunities; matches; day seminars. They are usually independent, run by student organizations, and often become official organizations of student organizations such as the British Students Union. Usually, they contain formal structures such as a president and a vice president. According to a previous study (Pittaway et al., 2011), the second form of social entrepreneurship can be defined as "club or organization entrepreneurship with a network." These clubs are a network of international companies led by students with similar philosophies and approaches. As (Li \& Yuan, 2019) stressed in their study, social entrepreneurship should focus on guiding students to pay attention to social problems around the world. They are experts in finding social problems in increasingly complex societies, nurturing students' ideas for joining social enterprises, and addressing social problems with their professional experience. Therefore, the promotion of social entrepreneurship must be integrated throughout the process in higher education. Social entrepreneurship also allows students to learn more and stimulate a sense of social responsibility and mission with comprehensive social education and future social entrepreneurship training for entrepreneurship students. Comprehensively, this provides a good theoretical foundation to students through additional-curricular activities.

\section{Career Readiness and Social Entrepreneurship}

A previous study by (Muslim \& Badlishah, 2016) states that higher education students are well prepared to face the challenges of relevant modern universities at present. As such, universities need to provide accurate students based on decision-making and informationseeking skills as well as the students' ability to improve interpersonal relationships and 
interpersonal communication (Buntat et al., 2013). These factors are important for measuring the level of professional readiness possessed by student professionals in the process of compiling a career plan. Career preparation refers to the personal ability to make career decisions that are appropriate for the family, organization, society, economy, etc. by considering the factors influencing career development (Sampson et al., 2013). Discussions and debates about the marketability of graduates are nothing new as they have been a broad topic of academic research for nearly 30 years (Helyer \& Lee, 2014). According to (Durham et al., 2014), most graduates do not have significant and clear work experience. In fact, the fields they are given do not suit the needs of organizations. Organizations from various industries use on-the-job training to help graduates compete in highly competitive fields in the working world. Garwe (2020) added that "in the past, employers were willing to hire skilled workers and train their environment to work." These skills are required for effective use in the workplace. According to (Owens, 2014), graduates need skills with the ability and quality to be effective in this changing global economic environment. Innovative, adaptable, and flexible employers are gradually believing that graduates have a competitive mindset. Researchers also support the ability of educational credibility to develop qualities, attributes, and skills that enable students to make effective contributions to the economy and society. Business training is clearly marketable and should be central to a credibility strategy for their career choice readiness.

\section{Conceptual Framework}

The conceptual framework is formed in accordance with the purpose of the discussion of this concept paper. Within this conceptual framework, the elements of career readiness are divided into five parts: students' skills and qualities, students' skills and knowledge, motivation, entrepreneurial ability, and opportunity recognition. Although these elements are the independent variables, additional activities of the social entrepreneurship curriculum are the intermediate variables and career readiness for a social entrepreneur is the dependent variable. The conceptual framework aims to see if relationships exist among these three variables in preparation for the public university students' careers as social entrepreneurs. The conceptual framework of the study is shown in Figure 1. This conceptual framework was adapted and modified from several previous studies. Specifically, the conceptual framework of Social Entrepreneurship Career Readiness of Public University Students was adapted from the studies by Olugbola (2017); Halim \& Sahid (2020); Anuar \& Sahid (2020) regarding career readiness, additional-curricular activities, and the willingness to be an entrepreneur. The variables in the framework were combined to identify the influence of additional-curricular activities (Anuar \& Sahid, 2020) for the relationship between career readiness Halim \& Sahid (2020) and social entrepreneurship career readiness (Olugbola, 2017). 
Table 1: Proposed Conceptual Framework

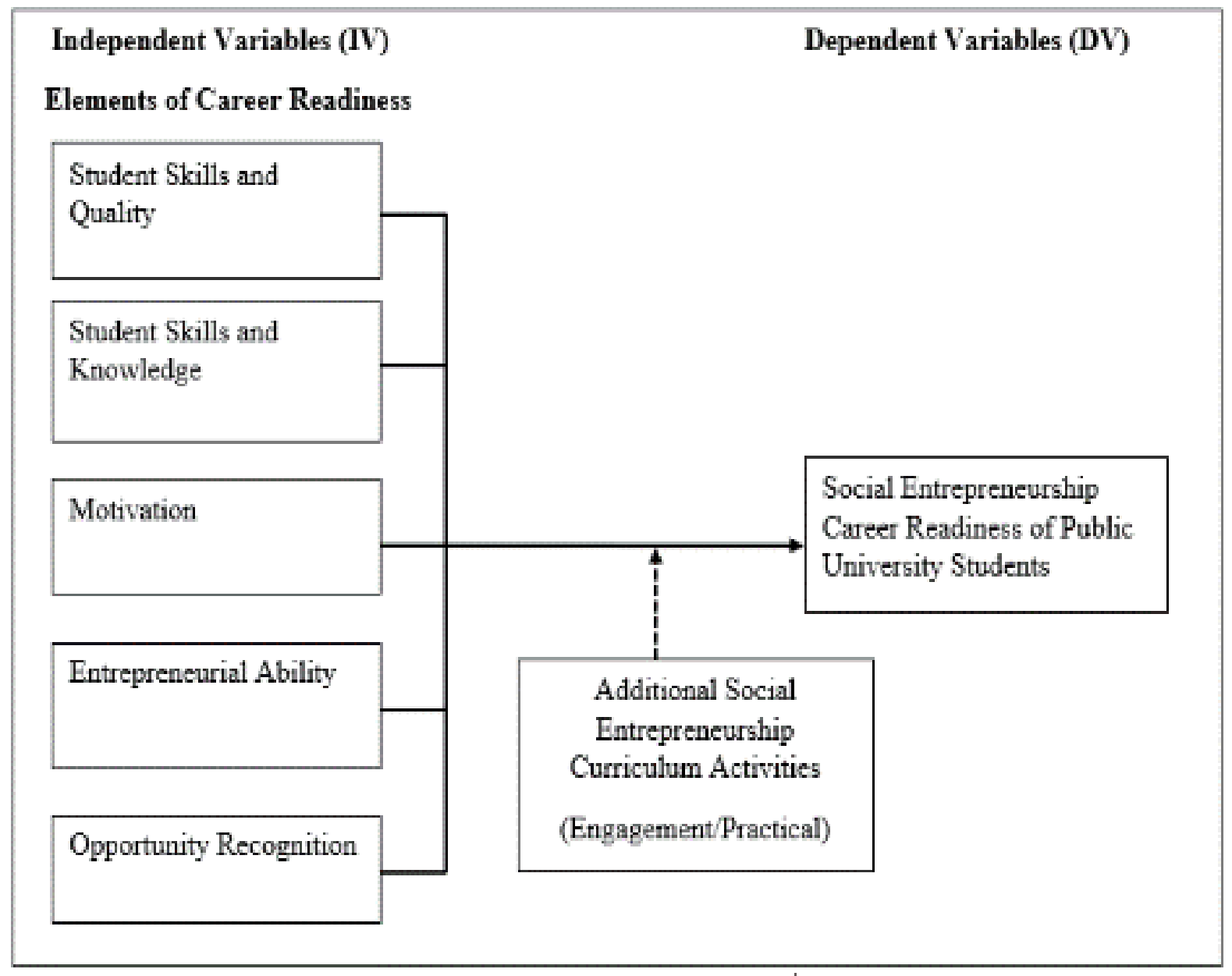

\section{Conclusion and Suggestions}

In conclusion, social entrepreneurship in higher education helps students to be more involved with social entrepreneurship through platforms such as educational institutions. It also helps provide great business and livelihood potential by working together to provide more practical skills, experience, and knowledge in the field of social entrepreneurship as a future career to graduates. In addition, increasing the number of groups in each higher education session can increase student interest in social entrepreneurship education. This could also result in more promotions, in tandem with an increase in the number of social entrepreneurs and apprentice clubs, including social entrepreneur awards and educational backgrounds. Besides, the importance of social entrepreneurship research on career readiness serves as the organizational vision to introduce leading social enterprises that develop innovative solutions to poverty and unemployment while actively sharing their experiences around the world. Therefore, the social goal is to promote the idea to maximize social impact, rather than selling models to maximize profits. Thus, social value is created by the organization and its social networks. Researchers have long regarded entrepreneurship as a driver of economic growth by offering more competition and productivity. As a result of the growing social challenges around the world, Entrepreneurship and Social Entrepreneurship are the two rapidly growing areas for students, researchers, and policymakers. However, there is limited information on the level of entrepreneurship and social entrepreneurship of students in Malaysia. In this document, business and social entrepreneurship are considered viable work options. 
Graduate careers are very limited in time because graduates are more interested in entrepreneurial endeavours than traditional careers. Besides involving the public in community service, social entrepreneurship is becoming one of the solutions to fight unemployment across the country, for example, through the ability to give work to others. Social entrepreneurship, in a broad sense, illustrates the need to drive social change and the potential for rewards with lasting changes and benefits that distinguish this field from its practitioners. When practiced in the economy based on factors, efficiencies, or innovation, the results can include reduced unemployment, increased innovation, and accelerated structural change in the economy. Based on the common understanding of social enterprises, social entrepreneurship is the process of realizing social enterprise, which encompasses all activities related to the recognition of opportunities to create social value and social enterprises that undertake them.

Examining the process of identifying and leveraging social enterprise opportunities, obstacles faced by social entrepreneurs, and how these obstacles can be overcome is useful and informative in the field of social entrepreneurship. The desire to be more proactive presents management challenges such that the competitive value of a social enterprise as an entrepreneur must be carefully aligned with its unprofitable social goals. However, finding a combination of useful and social skills alone is difficult and, as such, successful social enterprises must rely on building teams with shared values and the required skill profiles. Based on the proposal of this study, it is hoped that future studies will focus on management structure, skills, and the abilities of social enterprise managers in relation to organizational performance to provide evidence of the skills and competencies required by the field of social entrepreneurship to future graduates. Network or "Networking" plays a role in supporting an organization. As social enterprises tend to take place in small and local areas, they may use non-financial and non-commercial resources to create and operate them. However, little is known about the role of networks in identifying opportunities, providing resources and business advice to social entrepreneurs, identifying their support needs, and evaluating the usefulness of current advice resources. In this regard, it can be used to support infrastructure development. Social enterprises operate primarily at the local level, providing products and services that do not only influence individuals but also collectively influence local communities and societies.

Therefore, as a suggestion to the students studying the field of social entrepreneurship, exposure to this matter is essential. In service provision, access to services and skill levels help build social capital and cohesion by helping people acquire the skills they need later. There are many research opportunities related to measuring the performance of social enterprises. For example, in the UK, various non-profit organizations provide direct training to employees and volunteers of their socio-economic organizations, particularly in advanced education institutions. Many courses also teach the basics of setting up and running a social enterprise such as financing, marketing, and how to prepare a business plan. This is important for prospective graduates who want to take a professional certificate and the extensive training courses reflect the high demand. However, these courses tend to not worry about theoretical developments or political implications and the material is not suitable for academic courses. Social entrepreneurship is relatively new, and there are very few specialized courses available for undergraduate and graduate students for potential social entrepreneurs and those looking to work in the socio-economy. In the United States, Harvard University and Stanford University have established community and social enterprise programs, while in the United Kingdom, universities in Cambridge, Oxford, and Southampton offer graduate courses in 
social and community enterprises. In addition, British and American scholars have created a small group of specialized interests in social entrepreneurship. Therefore, universities in Malaysia should also create specific courses on social entrepreneurship as these countries. In addition, increased interest in social entrepreneurship at the policy level could stimulate the development of more courses in this field and, in turn, increase the demand for robust and rigorous research on social entrepreneurship. Research mapping the new academic curriculum of social and community companies, student recruitment and achievement patterns, and the evaluation and validation of internal and external courses provide important benchmarks for scholars and professionals.

There is at least one sign of a link between opportunity recognition and perspectives derived from what has been called the school of social entrepreneurial thinking by some past researchers. For example, in a very active "School of Social Innovation", social entrepreneurs often create new opportunities through innovation aimed at creating value and social change. Awareness of opportunities and business processes generate opportunity costs that are associated with delays and resources available to evaluate and use the opportunities. In addition, learning can also reduce opportunity costs by enhancing experience. The learning process is different throughout the business process; preparation (learning through analysis), incubation (learning through reflection and observation), evaluation (learning through experience and imagination), and effects (learning through experimentation and experience) were identified. Furthermore, this also includes a variety of learning styles.

Finally, along with learning, approaches to information processing have different possibilities to seize opportunities. This leads to the construction of opportunities through the processing and learning of information. Therefore, this study discusses and proposes a model of social entrepreneurship career readiness among university students, focusing on social entrepreneurship and the need to further explore students' career readiness as social entrepreneurs. In the field of entrepreneurship education, additional-curricular activities are hoped to help cultivate the attitudes of students in the national effort to increase the number of social entrepreneurs among prospective graduates or graduates, besides helping reduce unemployment and increase career opportunities in the business world to achieve the status of a developed and prosperous country. While effective education has a positive impact on other areas such as entrepreneurship, the researchers would also like to suggest that more empirical research be done to develop and strengthen educational theories on social entrepreneurship, career preparation, and curricular activities in institutions in the field of social entrepreneurship. This study should also stand out because the country's economy currently demands that the importance of entrepreneurship in the economic growth of a developed country be taken seriously. Besides, this study helps policymakers better understand the factors that influence the level of interest of college entrepreneurs, how to cultivate this interest, and the contribution of social entrepreneurs to productivity and job creation. Today's era has the potential to pave the way for the growth of social entrepreneurs; thus, social entrepreneurship can be a path to social, economic, and political inclusion, especially among young people.

This study proposed to enhance the process of how entrepreneurial career readiness elements influences graduate students to be a social entrepreneurs when they graduated from the university. Findings from this study could contribute the university by enhancing support and facilitate an entrepreneurship education eco-system much better. Furthermore, the university can also use the theoretical or the model as a guide to plan the next curricular 
that are suitable with the courses in university. This study will also strengthen the creation of mechanism support by government agencies to encourage students to become entrepreneurs in the future. The mechanisms are as follows; The Process-Ingredients and input necessity, outputs expectation, ongoing and continuous improvement for the activity plan. After that, The Understanding- An information on current condition of social entrepreneur, the direction next and how to get there. Next, The Impact- What is our impact on this study and how do we measure it? Lastly, The Social Entrepreneur Organization- Young generation organization, what are they doing, do we bring any impact, and have we fulfilled our objective? Finally, the model of social entrepreneurship career readiness is hoped to contribute to the ideas of prospective graduates as future careers at once can contribute to positive and effective job creation with the ability to change perspectives and focus on social business to motivate them.

\section{References}

Ab Wahid, H., Ahmad, N. L., Othman, N., \& Mustaffa, W. S. W. (2016). Kesosialan, Inovasi Dan Orientasi Pasaran Dalam Kalangan Pelajar Aktif Keusahawanan Sosial Di Universiti Awam Malaysia. Journal of Global Business and Social Entrepreneurship (GBSE) Vol, 3, 1-10.

Abdul Kadir, M. A. B., \& Sarif, M. S. (2016). Social Entrepreneurship, Social Entrepreneur and Social Enterprise:A Review of Concepts, Definitions and Development in Malaysia. Journal of Emerging Economies and Islamic Research, 4(2), 51. https://doi.org/10.24191/jeeir.v4i2.9086

Anuar, A. S., \& Sahid, S. (2020). Kerangka Konseptual Set Minda Keusahawanan, Inspirasi Keusahawanan dan Faktor Kognitif. Proceedings of The International Conference of Future Education and Advances, 53(9), 1689-1699. https://www.researchgate.net/publication/349198058_Kerangka_Konseptual_Set_ Minda_Keusahawanan_Inspirasi_Keusahawanan_dan_Faktor_Kognitif.

Augier, M., \& Teece, D. J. (Eds.). (2016). The Palgrave Encyclopedia of Strategic Management. The Palgrave Encyclopedia of Strategic Management. Published. https://doi.org/10.1057/978-1-349-94848-2

Brock, D. D., \& Steiner, S. (2009). Social Entrepreneurship Education: Is it Achieving the Desired Aims? SSRN Electronic Journal. Published. https://doi.org/10.2139/ssrn.1344419

Buntat, Y., Jabor, M., Saud, M. S., Mansor, S. M. S. S., \& Mustaffa, N. H. (2013). Employability Skills Element's: Difference Perspective Between Teaching Staff and Employers Industrial in Malaysia. Procedia - Social and Behavioral Sciences, 93, 1531-1535. https://doi.org/10.1016/j.sbspro.2013.10.077

Dacin, M. T., Dacin, P. A., \& Tracey, P. (2011). Social Entrepreneurship: A Critique and Future Directions. Organization Science, 22(5), 1203-1213. https://doi.org/10.1287/orsc.1100.0620

de Villiers, R. (2010). The incorporation of soft skills into accounting curricula: preparing accounting graduates for their unpredictable futures. Meditari Accountancy Research, 18(2), 1-22. https://doi.org/10.1108/10222529201000007

Doherty, B. (2015). Social Enterprise Journal 2015. Social Enterprise Journal, 11(1). https://doi.org/10.1108/sej-02-2015-0007

Edwards, S. (2001). Domestic violence and harassment: an assessment of the civil remedies. What Works in reducing domestic violence, 187-210 
Garwe, E. (2020). Does the timing of work integrated learning affect graduate employability outcomes? South African Journal of Higher Education, 35(4).

https://doi.org/10.20853/34-5-4225

Gasparin, M., Green, W., Lilley, S., Quinn, M., Saren, M., \& Schinckus, C. (2021). Business as unusual: A business model for social innovation. Journal of Business Research, 125, 698-709. https://doi.org/10.1016/j.jbusres.2020.01.034

Germak, A. J., \& Robinson, J. A. (2013). Exploring the Motivation of Nascent Social Entrepreneurs. Journal of Social Entrepreneurship, 5(1), 5-21. https://doi.org/10.1080/19420676.2013.820781

Ghalwash, S., Tolba, A., \& Ismail, A. (2017). What motivates social entrepreneurs to start social ventures? Social Enterprise Journal, 13(3), 268-298.

https://doi.org/10.1108/sej-05-2016-0014

Gregory, D. J., \& Anderson, B. B. (2006). Framing a theory of social entrepreneurship: Building on two schools of practice and thought. Research on social entrepreneurship, 39-66.

Gomis, R., Kapsos, S., \& Kuhn, S. (2020). World employment and social outlook: trends 2020. ghano, P. D., Suyono, H., \& Sunarjo, S. (2019). Competency Model of Social Entrepreneurs: Learning from Successful Indonesian Social Entrepreneurs. International Journal of Research in Business and Social Science (2147-4478), 8(3), 94-110.

Halim, N. H., \& Sahid, S. (2020). Kemahiran Kesediaan Kerja, Efikasi Kendiri, Tingkah Laku Keusahawanan dan Eksplorasi Kerjaya dalam kalangan Graduan (Work Readiness Skills, Self-Efficacy, Entrepreneurial Behavior and Career Exploration among Graduates). Akademika, 90(3).

Haugh, H. (2005). A research agenda for social entrepreneurship. Social Enterprise Journal, 1(1), 1-12. https://doi.org/10.1108/17508610580000703

Helyer, R. \& Lee, D. (2014). The Role of Work Experience in the Future Employability of Higher Education Graduates. Higher Education Quarterly 68(3), 348-372. doi:10.1111/hequ.12055

Indrasari, M., Purnomo, R. B., Syamsudin, N., \& Yunus, E. (2018). Development Entrepreneurship Intention Among Students. IJEBD (International Journal Of Entrepreneurship And Business Development), 1(2), 146-154. https://doi.org/10.29138/ijebd.v1i2.556

Kannampuzha, M., \& Hockerts, K. (2019). Organizational social entrepreneurship: scale development and validation. Social Enterprise Journal, 15(3), 290-319. https://doi.org/10.1108/sej-06-2018-0047

Kanungo, R., \& Dash, S. R. (2016). A Conceptual View on Companies Act 2013: With Special reference to Share Capital. Intercontinental Journal of Finance Research Review, 4.

Karlesky, M. J. (2015). Identifying entrepreneurial opportunities: Cognition and categorization in nascent entrepreneurs (Doctoral dissertation).

Koe Hwee Nga, J., \& Shamuganathan, G. (2010). The Influence of Personality Traits and Demographic Factors on Social Entrepreneurship Start Up Intentions. Journal of Business Ethics, 95(2), 259-282. https://doi.org/10.1007/s10551-009-0358-8

Li, L., \& Yuan, F. (2019). Integrating Social Entrepreneurship into Higher Education in the New Era. Proceedings of the 2019 3rd International Conference on Education, Economics and Management Research (ICEEMR 2019). Published.

https://doi.org/10.2991/assehr.k.191221.039

Mair, J., \& Marti, I. (2004). Social entrepreneurship: What are we talking about? A framework for future research (No. D/546). IESE Business School.Mair, J. \& Marti, I. 2004. Social 
entrepreneurship: What are we talking about? A framework for future research. IESE Research Papers (April 2004).

Mansor, M., \& Rashid, A. M. (2013). Career indecision: a cross-sectional survey among students of national youth skills training institutes. Middle-East Journal of Scientific Research, 17(8), 1073-1079.

Monllor, J., \& Attaran, S. (2008). Opportunity recognition of social entrepreneurs: an application of the creativity model. International Journal of Entrepreneurship and Small Business, 6(1), 54. https://doi.org/10.1504/ijesb.2008.017389

Noruzi, M. R., Westover, J. H., \& Rahimi, G. R. (2010). An Exploration of Social Entrepreneurship in the Entrepreneurship Era. Asian Social Science, 6(6). https://doi.org/10.5539/ass.v6n6p3

Oliveri, M. E., Lawless, R., \& Molloy, H. (2017). A Literature Review on Collaborative Problem Solving for College and Workforce Readiness. ETS Research Report Series, 2017(1), 127. https://doi.org/10.1002/ets2.12133

Olugbola, S. A. (2017). Exploring entrepreneurial readiness of youth and startup success components: Entrepreneurship training as a moderator. Journal of Innovation \& Knowledge, 2(3), 155-171. https://doi.org/10.1016/j.jik.2016.12.004

Owens, J., \& Tibby, M. (2014). Enhancing employability through enterprise education: Examples of good practice in higher education.

Pittaway, L., Rodriguez-Falcon, E., Aiyegbayo, O., \& King, A. (2011). The role of entrepreneurship clubs and societies in entrepreneurial learning. International Small Business Journal: Researching Entrepreneurship, 29(1), 37-57. https://doi.org/10.1177/0266242610369876

Prikshat, V., Nankervis, A., Burgess, J., \& Dhakal, S. (2018). Conceptualising Graduate WorkReadiness: Theories, Concepts and Implications for Practice and Research. Work, Organization, and Employment, 15-29. https://doi.org/10.1007/978-981-13-09748_2

Raftopoulos, M., Coetzee, S., \& Visser, D. (2009). Work-readiness skills in the Fasset Sector. SA Journal of Human Resource Management, 7(1). https://doi.org/10.4102/sajhrm.v7i1.196

Roper, J., \& Cheney, G. (2005). The meanings of social entrepreneurship today. Corporate Governance: The International Journal of Business in Society, 5(3), 95-104. https://doi.org/10.1108/14720700510604733

Saebi, T., Foss, N. J., \& Linder, S. (2018). Social Entrepreneurship Research: Past Achievements and Future Promises. Journal of Management, 45(1), 70-95. https://doi.org/10.1177/0149206318793196

Sampson, J. P., McClain, M. C., Musch, E., \& Reardon, R. C. (2013). Variables Affecting Readiness to Benefit from Career Interventions. The Career Development Quarterly, 61(2), 98-109. https://doi.org/10.1002/j.2161-0045.2013.00040.x

Sánchez, J. C. (2013). The Impact of an Entrepreneurship Education Program on Entrepreneurial Competencies and Intention. Journal of Small Business Management, 51(3), 447-465. https://doi.org/10.1111/jsbm.12025

Schleicher, A. (2020). The impact of COVID-19 on education insights from education at a glance 2020. Retrieved from oecd. org website: https://www. oecd. org/education/the-impact-of-covid-19-on-education-insights-education-at-a-glance2020. pdf. 
Seelos, C., \& Mair, J. (2005). Social entrepreneurship: Creating new business models to serve the poor. Business Horizons, 48(3), 241-246. https://doi.org/10.1016/j.bushor.2004.11.006

Short, J. C., Ketchen, D. J., Shook, C. L., \& Ireland, R. D. (2009). The Concept of "Opportunity" in Entrepreneurship Research: Past Accomplishments and Future Challenges. Journal of Management, 36(1), 40-65. https://doi.org/10.1177/0149206309342746

Teng, Y., Li, K., Pan, W., \& Ng, T. (2018). Reducing building life cycle carbon emissions through prefabrication: Evidence from and gaps in empirical studies. Building and Environment, 132, 125-136. https://doi.org/10.1016/j.buildenv.2018.01.026

Thompson, J. L. (2002). The world of the social entrepreneur. International Journal of Public Sector Management, 15(5), 412-431. https://doi.org/10.1108/09513550210435746

Tishler, B. J. (2018). Exploring Knowledge and Awareness of Social Entrepreneurship (Doctoral dissertation, Nova Southeastern University).

Vallejo-Fiallos, M. D. R. (2019). Corporate Social Entrepreneurship. Advances in Higher Education and Professional Development, 305-331. https://doi.org/10.4018/978-15225-5837-8.ch014

Warnick, B. J., Murnieks, C. Y., McMullen, J. S., \& Brooks, W. T. (2018). Passion for entrepreneurship or passion for the product? A conjoint analysis of angel and VC decision-making. Journal of Business Venturing, 33(3), 315-332. https://doi.org/10.1016/j.jbusvent.2018.01.002

Worsham, L., Markewitz, D., Nibbelink, N. P., \& West, L. T. (2012). A Comparison of Three Field Sampling Methods to Estimate Soil Carbon Content. Forest Science, 58(5), 513522. https://doi.org/10.5849/forsci.11-084

Wronka-Pośpiech, M. (2016). The identification of skills and competencies for effective management in social enterprises. A managerial perspective. Management, 20(1), 4057. https://doi.org/10.1515/manment-2015-0023 